\title{
Study of the physical and chemical properties of materials based on polymer complexes of some water-soluble polymers
}

\author{
(C) Marina V. Bazunova, ${ }^{*+}$ Robert A. Mustakimov, Nadezhda V. Dmitrieva, \\ Diana R. Dayanova, and Andrey A. Bazunov \\ Department of Macromolecular Compounds and General Chemical Technology. Chemical Faculty. \\ Bashkir State University. Zaki Validi St., 32. Ufa, 450076. Republic of Bashkortostan. Russia. \\ Phone:+7 (347) 229-97-24. E-mail: mbazunova@mail.ru
}

\begin{abstract}
*Supervising author; ${ }^{+}$Corresponding author Keywords: polymer complexes, poly- $N$-vinylpyrrolidone, chitosan succinyl, carboxymethyl cellulose, polyethylene glycol.
\end{abstract}

\begin{abstract}
Polymer complexes based on water-soluble physiologically-neutral polymers are promising for creating biomedical materials used in targeted delivery systems of drugs, enzymes or genes, as well as for encapsulating biological substances in biomedicine. In this work, the creation of film materials based on polymer complexes has used the sodium salt of succinyl chitosan, polyvinylpyrrolidone, sodium salt of carboxymethylcellulose, polyethylene glycol. Polyvinylpyrrolidone and polyethylene glycol are characterized by unsatisfactory a film-forming and gel-forming property, which limits their application in medical practice. These shortcomings have been compensated by the introduction of polysaccharides. It has been shown that the variation in composition of the studied polymer complexes allows changing purposefully the hydrophilic-hydrophobic balance of the surface and sorption properties of polymer films based on them. The preparation of polymer complexes consisted of adding a portion of poly- $N$-vinylpyrrolidone or polyethylene glycol to solutions of the sodium salt of succinyl chitosan or sodium salt of carboxymethylcellulose so that the ratio of the components of the complex was equimolar. Films based on polymer complexes were prepared by the method of pouring solutions of polymer mixtures with a concentration of $1 \mathrm{~mol} / \mathrm{L}$ onto a previously defatted surface of a Petri dish. The thickness of the film samples was maintained constant and equal to 0.1 $\mathrm{mm}$. It was shown that the preparation of polymer complexes of the sodium salt of chitosan succinyl or the sodium salt of carboxymethyl cellulose with poly-( $N$-vinylpyrrolidone) or polyethylene glycol allows one to purposefully change the hydrophilic-hydrophobic balance of the surface of polymer films based on them. Also, film materials based on the studied polymer complexes have satisfactory sorption properties for water vapor. These facts suggest that systems based on polymer complexes of the sodium salt of chitosan succinyl or sodium salt of carboxymethylcellulose with poly ( $N$-vinyl pyrrolidone) or polyethylene glycol can serve as the basis for the creation of film or gel polymer materials for medical use.
\end{abstract}

\section{References}

[1] Heidi Vogt Sther, Hilde K. Holme, Gjertrud Maurstad, Olav Smidsrod. Carbohydrate Polymers. 2008. Vol.74. P.813-821.

[2] G.Kh. Dzhulieva, K.M. Makhkamov, Z.K. Mukhidinov. Composition based on carboxymethyl cellulose and zein as a carrier of medicinal substances. $D A N R T$. 2009. No.11. URL:

https://cyberleninka.ru/article/n/kompozitsiya-na-osnove-karboksimetiltsellyulozy-i-zeina-kak-nositellekarstvennyh-veschestv (accessed date: 05.20.2020).

[3] C. Randy, B. Tzi, Jack H., Wai Y. Mar Drugs. 2015. Vol.13. No.8. P.5156-5186.

[4] A.G. Ivanov, V.A. Mukhina, V.A. Prikhodko, N.A. Anisimova, N.V. Kirillova. Insulinomimetically active macromolecular metal complexes of vanadium based on poly- $N$-vinylpyrrolidone. Part 2. Assessment of the hypoglycemic activity of the vanadium macromolecular metal complex. Butlerov Communications. 2019. Vol.59. No.9. P.110-116. DOI: 10.37952/ROI-jbc-01/19-59-9-110 
[5] V.F. Kurenkov, S.A. Shevtsova, T.A. Zhelonkina, I.V. Kozhevnikova. Polymer-polymer complexes based on copolymers of $N$-vinylpyrrolidone with sodium salt of 2-acrylamido-2-methylpropanesulfonic acid. Butlerov Communications. 2005. Vol.6. No.1. P.57-59. ROI-jbc-01/05-6-1-57

[6] C. Florence, J. Christine. European Polymer Journal. 2013. Vol.49. No.4. P.780-792.

[7] F.P. Sidelkovskaya. Chemistry of $N$-vinylpyrrolidone and its polymers. Nauka, Moscow. 1970. 134p. (russian)

[8] V.Yu. Baranovsky, L. A. Kazarin, A. A. Litmanovich, I. M. Papisov, V. A. Kabanov. High mole. Comp. 1982. Vol.24. No.7. P.1480-1483. (russian)

[9] A.N. Ivankin, V.I. Panferov, H.A. Fakhretdinov, N.L. Vostrikova, A.V. Kulikovsky, P.M. Golovanova. Nanomicrocompositional wound dressings based on collagen and carboxymethyl cellulose. Bulletin of Moscow State Forest University. Forest Bulletin. 2015. Vol.19. No.1. P.41-45. (russian)

[10] A.M. Bochok, I.L. Shevchuk, L.M. Kalyuzhnaya. Properties of aqueous solutions of mixtures of carboxymethyl cellulose of varying degrees of ionization with polyvinyl alcohol. Journal of Applied Chemistry. 2010. Vol.83. Iss.4. P.660-665. (russian)

[11] K.S. Desyatnichenko, L.P. Istranov, E.V. Istranova, S.G. Kurdyumov, L.N. Maksimovskaya. Gel for bone regeneration. Patent for invention RU 2360663 C1, 07/10/2009. Application No. 2008118086/15 dated 05/08/2008. (russian)

[12] M.V. Bazunova, R.Yu. Lazdin, L.A. Sharafutdinova, E.I. Kulish. Plasticized films based on chitosan succinyl. Butlerov Communications. 2019. Vol.60. No.10. P.42-47. DOI: 10.37952/ROI-jbc-01/19-60$10-42$

[13] I.I. Gilmutdinov, I.M. Gilmutdinov, I.V. Kuznetsova, A.N. Sabirzyanov. Preparation of ibuprofenpolyethylene glycol 4000, methylparaben-polyethylene glycol 4000 composite particles and study of their morphology and dispersion. Bulletin of Kazan Technological University. 2013. Vol.16. No.13. P.96-98. (russian)

[14] J. Khandare, T. Minko. Prog. Polym. Sci. 2006. Vol.31. P.359-397.

[15] P. Anand, S.G. Thomas, A.B. Kunnumakkara, C. Sundaram, K.B. Harikumar, B. Sung, S.T. Tharakan, K. Misra, I.K. Priyadarsini, K.N. Rajasekharan. Ag( garwal B.B. Biochem. Pharmacol. 2008. Vol.76. P.1590-1611.

[16] M.V. Bazunova, L.A. Sharafutdinova, R.Y. Lazdin, V.V. Chernova, D.N. Mixonov, V.P. Zakharov. Medical materials based on chitosan succinamide-glycerol systems. Applied Biochemistry and Microbiology. 2018. Vol.54. No.5. P.474-477.

[17] R.S. Navath, B. Wang, S. Kannan, R. Romero, R.M. Kannan. J. Controlled Release. 2010. Vol.142. P.447-456.

[18] M.V. Bazunova, R.A. Mustakimov, E.I. Kulish. Study of the features of the formation of polyelectrolyte complexes of polyvinylpyrrolidone-succinamide chitosan. Bulletin of the Technological University. 2019. Vol.22. No.7. P.5-14. (russian)

[19] J.D. Andrade, D.E. Gregonis, L.M. Smith. Polymer surface dynamics. In: Andrade J.D., editor. Surface and interfacial aspects of biomedical polymers. NY: Plenum Press. 1985. Vol.1. P.15-41.

[20] S.A. Bogdanova, A.O. Ebel, M.V. Slobozhaninova, V.P. Barabanov. Surface tension and wetting ability of block copolymers of alkylene oxides. Chemistry and computer simulation. Butlerov Communications. 2002. Vol.2. No.9. P.25-28. ROI-jbc-01/02-2-9-25

[21] D.V. Shablin, S.G. Pavlenko, A.A. Evlevsky et al. Fundamental Research. 2013. No.12. P.361. (russian) 